\title{
Interactive Effect of PPFM on Growth and Yield of Cyamopsis tetragonoloba (L.) under Water Stress
}

\author{
A. Nithya Devi* and M. Subasri
}

Horticultural College \& Research Institute for Women, Tiruchirappalli - 620 027, India

*Corresponding author

\section{A B S T R A C T}

\section{Keywords}

Cluster bean, Water stress, PPFM growth, Yield

Article Info

Accepted: 12 August 2020 Available Online: 10 September 2020
Cluster bean is generally considered as a drought tolerant crop; few studies have shown that water stress experienced during critical growth stages can lead to substantial reduction of yield. Pot culture experiments were conducted in the Horticultural College and Research Institute for Women, Tiruchirappalli to study the response of cluster bean plants to drought and Pink Pigmented Facultative Methylotrophs (PPFM), imposed at critical growth stages, in terms of growth and yield. Cluster bean variety Pusa Navbahar seedlings were raised under pot culture conditions. In this study, six treatments were compared in varying water levels for yield enhancement in cluster bean under drought. Cluster bean seeds were inoculated with PPFM either alone or in combination with soil treatment and foliar spray. The experiment was carried out with six treatments viz., control, seed treatment $(0.1 \%)$, soil application $(0.2 \%)$, foliar application $(0.1 \%)$, seed treatment $(0.1 \%)$ + soil application $(0.2 \%)$, seed treatment $(0.1 \%)+$ foliar spray $(0.1 \%)$. The effect of PPFM on cluster bean growth was also examined where water supply to plants was regulated during flowering and pod filling stage. The plants were observed for germination percentage, number of leaves, leaf area, shoot length, root length, days to first flowering, days to first harvest, PPFM population on phyllosphere and rhizosphere, proline content, yield, crop duration. Results showed that the cluster bean seeds treated with PPFM (seed treatment $-0.1 \%+$ foliar spray $-0.1 \%$ ) recorded the highest germination percentage $(97.5$ $\%)$. The same treatment also recorded the highest plant height $(67.5 \mathrm{~cm})$, number of leaves (20.8), leaf area $\left(63.0 \mathrm{~cm}^{2}\right)$ and pod yield of $102.5 \mathrm{~g} /$ plant with the longest duration of 115 days. Though the plants grown in the low water regime produced low yield when compared to normally irrigated plants, it recorded significantly higher yield and yield components in response to PPFM application when compared to control plants maintained under drought stress. Pink Pigmented Facultative Methylotrophs (PPFM) has been identified as promising bacteria for enhanced cluster bean growth and yield probably due to the production of phytohormones. This study demonstrates that PPFM may enhance cluster bean yield in an environment characterized by soil moisture stress or low rainfall during growth period.

\section{Introduction}

Throughout evolutionary time, plants have been confronted with changing environmental conditions, among which water stress is considered as the most important abiotic factors limiting plant growth and yield in 
many areas. The response of plants to water stress depends on several factors such as genotype, developmental stage of the crop, severity and duration of stress. The prominent effects of water stress on the crops include reduction in growth, nodulation and photosynthetic activity. In recent years, the use of Pink Pigmented Facultative Methylotrophs (PPFM) have generated great interests in agriculture, by reducing the damage from drought stress and providing sustainable solutions for crop production in such climates. Cyamopsis tetragonoloba (L.) Taub. commonly known as cluster bean, summer moong or "guar" is a potential vegetable and industrial leguminous crop occupying a major portion of moisture deficient areas. Being a rich source of gum and protein, it has become an important industrial crop in recent years. Cluster bean is generally considered as a drought tolerant crop; few studies have shown that water stress experienced during critical growth stages can lead to substantial reduction of yield. Boutra and Sanders (2001) reported that water stress during flowering and pod-filling stage decreased seed yield. PPFMs are aerobic, gram-negative bacteria which can fasten seed germination, seedling growth, accelerate vegetative growth, increase the leaf area index and chlorophyll content, induce earliness in flowering, fruit set and maturation, improves fruit quality, color and seed weight, yield increase and mitigate drought. PPFMs exude osmoprotectants (sugars and alcohols) on the surface of host plants. This matrix may help to protect the plants from desiccation and high temperatures.

Keeping the above in view, the present investigation was undertaken to evaluate the effect of PPFM on cluster bean with different stages of application which have the maximum capability of increasing the plant growth and yield under water stress conditions.

\section{Materials and Methods}

The present investigation was carried out to study the effect of PPFM on the growth and yield of cluster bean and to identify the effect of PPFM on drought tolerance at the experimental farm of the Horticultural College and Research Institute for Women, Tiruchirapalli during 2016 in pot culture experiment on Pusa Navbahar variety.

The cluster bean seedlings were sown in earthen pots containing air dried red soil and farmyard manure in 3:1 proportion. Half of the pots were well watered throughout the experiment, while the other half were subjected to water stress conditions by skipping one irrigation at three stages i.e. vegetative stage, flowering stage and pod formation stage. After each stage, short term stress period was applied and the plants were permitted to recover by re-watering until harvesting (recovery period). The experiment was arranged in a experimental farm under net-house with six treatments (T1 - Control, T2 - Seed Treatment, T3 - Soil Application, T4 - Foilar Spray, T5- Seed Treatment + Soil application and T6- Seed Treatment + Foliar spray) with two different conditions of Normal $\left(\mathrm{W}_{1}\right)$ and Drought $\left(\mathrm{W}_{2}\right)$ were laid out in Completely Randomized Design (CRD) with factorial concept with four replications.

The foliar spray was done at 2 stages i.e., before flowering and pod filling stage. PPFM was diluted in the ratio of 1:1 with water and sprayed. The observations were recorded on biometrical aspects viz., growth and yield. The data on germination percentage were recorded at 7 DAS. The height of plant $(\mathrm{cm})$ and number of leaves per plant were recorded at 30, 45 and 60 DAS. In respect of days to first flowering, days to first harvest, duration of the crop was expressed in days. Leaf Area was expressed in $\mathrm{cm}^{2}$. Root length was measured during thinning and at the end of 
the crop and expressed in $\mathrm{cm}$. The pod weight per plant was recorded and expressed in g/plant. Proline content of the leaf was determined by the method of Bates et al (1973) and expressed in $\mu \mathrm{g} \mathrm{g}^{-1}$ of fresh weight. PPFMs populations were enumerated on both abaxial and adaxial surfaces of leaves by a leaf imprinting method (Holland et al., 1992) and expressed in cfu per leaflet.

The rhizosphere bacterial population $\left(\mathrm{cfu} \mathrm{g}^{-1}\right.$ of soil) was determined by dilution plating of the sample on AMS agar added with methanol. The data recorded were subjected to statistical scrutiny by analysis of variance using the AgRes statistical software (1994, Pascal International Software Solutions). Conclusions were drawn from the results obtained from the package.

\section{Results and Discussion}

The drought stress had an undesirable effect on growth, yield in water stressed plants in comparison to well watered plants. Results showed that the cluster bean seeds treated with PPFM (seed treatment $-0.1 \%+$ foliar spray - $0.1 \%$ ) recorded the highest germination percentage $(97.5 \%)$ (Table 1$)$. The same treatment also recorded the highest plant height $(67.5 \mathrm{~cm})$, number of leaves (20.8) (Table 2), leaf area $\left(63.0 \mathrm{~cm}^{2}\right)$ and pod yield of $102.5 \mathrm{~g} /$ plant with the longest duration of 115 days (Table 3). Though the plants grown in the low water regime produced low yield when compared to normally irrigated plants, it recorded significantly higher yield and yield components in response to PPFM application when compared to control plants maintained under drought stress. Data on yield showed that bio-inoculation of cluster bean plant with PPFM significantly increased leaf area, number of leaves, earliness in flowering, number of pods and consequently higher yields over control in the plants exposed to water stress as well as under normal condition. Similar results are reported by Abdelmoneim et al., (2014) in maize plant inoculated with PPFM under water stress condition. PPFMs exude osmoprotectants (sugars and alcohols) on the surface of host plants - protect the plants from drought stress.

Table.1 Effect of PPFM on Germination (\%) and leaf area $\left(\mathrm{cm}^{2}\right)$ of cluster bean

\begin{tabular}{|c|c|c|c|c|c|c|}
\hline \multirow[t]{2}{*}{ Treatments } & \multicolumn{3}{|c|}{ Germination (\%) } & \multicolumn{3}{|c|}{ Leaf area $\left(\mathrm{cm}^{2}\right)$} \\
\hline & $\begin{array}{c}\mathrm{W}_{1}- \\
\text { Normal } \\
\text { condition }\end{array}$ & $\begin{array}{c}\mathrm{W}_{2}- \\
\text { Drought } \\
\text { condition }\end{array}$ & $\begin{array}{c}\mathbf{T} \\
\text { Mean }\end{array}$ & $\begin{array}{c}\mathrm{W}_{1}- \\
\text { Normal } \\
\text { condition }\end{array}$ & $\begin{array}{c}\mathrm{W}_{2}- \\
\text { Drought } \\
\text { condition }\end{array}$ & T Mean \\
\hline $\mathbf{T}_{1}-$ Control & 87.5 & 88.0 & 87.8 & 45.0 & 36.0 & 40.5 \\
\hline $\mathrm{T}_{2}$ - Seed treatment of PPFM & 97.0 & 96.0 & 96.5 & 50.4 & 43.2 & 46.8 \\
\hline$T_{3}$ - Soil application of PPFM & 94.0 & 94.5 & 94.3 & 52.2 & 44.1 & 48.2 \\
\hline $\mathbf{T}_{4}$ - Foliar spray of PPFM & 88.0 & 87.5 & 87.8 & 58.5 & 49.5 & 54.0 \\
\hline $\begin{array}{l}\mathrm{T}_{5}-\text { Seed treatment }+ \text { Soil } \\
\text { application of PPFM }\end{array}$ & 97.0 & 97.0 & 97.0 & 54.0 & 45.9 & 50.0 \\
\hline $\begin{array}{l}\text { T}_{6} \text { - Seed treatment }+ \text { Foliar } \\
\text { spray of PPFM }\end{array}$ & 97.5 & 96.5 & 97.0 & 63.0 & 54.0 & 58.5 \\
\hline W Mean & 93.5 & 93.3 & 93.4 & 53.9 & 45.5 & 49.7 \\
\hline & W & $\mathbf{T}$ & $\mathbf{W} \times \mathbf{T}$ & $\mathbf{W}$ & $\mathbf{T}$ & $\mathbf{W} \times \mathbf{T}$ \\
\hline $\mathrm{CD}(\mathrm{P}=\mathbf{0 . 0 5})$ & NS & 1.73 & 2.45 & 0.53 & 0.93 & 1.31 \\
\hline SEd & NS & 0.85 & 1.21 & 0.26 & 0.45 & 0.64 \\
\hline
\end{tabular}


Table.2 Effect of PPFM on Plant Height $(\mathrm{cm})$ and number of leaves of cluster bean on $60^{\text {th }}$ DAS

\begin{tabular}{|l|c|c|c|c|c|c|}
\hline \multirow{2}{*}{ Treatments } & \multicolumn{3}{|c|}{ Plant Height $(\mathbf{c m})$} & \multicolumn{3}{c|}{ Number of leaves } \\
\cline { 2 - 7 } & $\begin{array}{c}\mathbf{W}_{\mathbf{1}}- \\
\text { Normal } \\
\text { condition }\end{array}$ & $\begin{array}{c}\mathbf{W}_{\mathbf{2}}- \\
\text { Drought } \\
\text { condition }\end{array}$ & $\mathbf{T}$ Mean & $\begin{array}{c}\mathbf{W}_{\mathbf{1}}- \\
\text { Normal } \\
\text { condition }\end{array}$ & $\begin{array}{c}\mathbf{W}_{\mathbf{2}}- \\
\text { Drought } \\
\text { condition }\end{array}$ & $\begin{array}{c}\mathbf{T} \\
\text { Mean }\end{array}$ \\
\hline $\mathbf{T}_{\mathbf{1}}$ - Control & 55.5 & 47.2 & $\mathbf{5 1 . 4}$ & 14.9 & 10.6 & $\mathbf{1 2 . 8}$ \\
\hline $\mathbf{T}_{\mathbf{2}}$ - Seed treatment of PPFM & 61.8 & 52.5 & $\mathbf{5 7 . 2}$ & 16.6 & 14.1 & $\mathbf{1 5 . 4}$ \\
\hline $\mathbf{T}_{\mathbf{3}}$ - Soil application of PPFM & 58.3 & 49.5 & $\mathbf{5 3 . 9}$ & 17.2 & 14.6 & $\mathbf{1 5 . 9}$ \\
\hline $\mathbf{T}_{\mathbf{4}}$ - Foliar spray of PPFM & 60.7 & 51.6 & $\mathbf{5 6 . 2}$ & 19.3 & 16.4 & $\mathbf{1 7 . 9}$ \\
\hline $\begin{array}{l}\mathbf{T}_{\mathbf{5}} \text { - Seed treatment + Soil application } \\
\text { of PPFM }\end{array}$ & 63.3 & 53.8 & $\mathbf{5 8 . 6}$ & 17.8 & 15.1 & $\mathbf{1 6 . 5}$ \\
\hline $\begin{array}{l}\mathbf{T}_{\mathbf{6}} \text { - Seed treatment + Foliar spray of } \\
\text { PPFM }\end{array}$ & 67.5 & 57.4 & $\mathbf{6 2 . 5}$ & 20.8 & 17.7 & $\mathbf{1 9 . 3}$ \\
\hline W Mean & $\mathbf{6 1 . 2}$ & $\mathbf{5 2 . 0}$ & $\mathbf{5 6 . 6}$ & $\mathbf{1 7 . 8}$ & $\mathbf{1 4 . 8}$ & $\mathbf{1 6 . 3}$ \\
\hline & $\mathbf{W}$ & $\mathbf{T}$ & $\mathbf{W} \mathbf{x}$ T & $\mathbf{W}$ & $\mathbf{T}$ & $\mathbf{W} \mathbf{x}$ T \\
\hline CD (P=0.05) & 0.60 & 1.04 & 1.48 & 0.17 & 0.30 & 0.43 \\
\hline SEd & 0.29 & 0.51 & 0.73 & 0.08 & 0.15 & 0.21 \\
\hline
\end{tabular}

Table.3 Effect of PPFM on Yield (g/plant) and Crop duration (days) of cluster bean

\begin{tabular}{|c|c|c|c|c|c|c|}
\hline \multirow[b]{2}{*}{ Treatments } & \multicolumn{3}{|c|}{ Yield (g/plant) } & \multicolumn{3}{|c|}{ Crop duration (days) } \\
\hline & $\begin{array}{c}\mathrm{W}_{1}- \\
\text { Normal } \\
\text { condition }\end{array}$ & $\begin{array}{c}\mathrm{W}_{2}- \\
\text { Drought } \\
\text { condition }\end{array}$ & $\begin{array}{c}\text { T } \\
\text { Mean }\end{array}$ & $\begin{array}{c}\mathrm{W}_{1}- \\
\text { Normal } \\
\text { condition }\end{array}$ & $\begin{array}{c}\mathrm{W}_{2}- \\
\text { Drought } \\
\text { condition }\end{array}$ & T Mean \\
\hline$T_{1}-$ Control & 55.5 & 34.5 & 45.0 & 108.2 & 99.0 & 103.6 \\
\hline $\mathrm{T}_{2}$ - Seed treatment of PPFM & 78.4 & 55.0 & 66.7 & 110.8 & 104.2 & 107.5 \\
\hline$T_{3}$ - Soil application of PPFM & 82.8 & 60.2 & 71.5 & 111.5 & 103.5 & 107.5 \\
\hline$T_{4}$ - Foliar spray of PPFM & 93.0 & 72.5 & 82.8 & 110.5 & 104.0 & 107.3 \\
\hline $\begin{array}{l}T_{5}-\text { Seed treatment }+ \text { Soil } \\
\text { application of PPFM }\end{array}$ & 95.5 & 78.0 & 86.8 & 112.2 & 106.8 & 109.5 \\
\hline $\begin{array}{l}\mathrm{T}_{6} \text { - Seed treatment + Foliar } \\
\text { spray of PPFM }\end{array}$ & 102.5 & 85.2 & 93.9 & 115.0 & 110.5 & 112.8 \\
\hline \multirow[t]{2}{*}{ W Mean } & 84.6 & 64.2 & 74.4 & 111.4 & 104.7 & 108.0 \\
\hline & $\mathbf{W}$ & $\mathbf{T}$ & $\mathbf{W} \times \mathbf{T}$ & $\mathbf{W}$ & $\mathbf{T}$ & $\mathbf{W} \times \mathbf{T}$ \\
\hline $\mathrm{CD}(\mathrm{P}=\mathbf{0 . 0 5})$ & 1.18 & 2.06 & 2.91 & 1.15 & 1.99 & 2.82 \\
\hline SEd & 0.58 & 1.01 & 1.43 & 0.56 & 0.98 & 1.39 \\
\hline
\end{tabular}


Table.4 Effect of PPFM on Dynamics of PPFM population in phyllosphere (cfu/leaflet) and rhizosphere $\left(10^{3} \mathrm{cfu} / \mathrm{g}\right.$ of soil) of cluster bean on 60 DAS

\begin{tabular}{|c|c|c|c|c|c|c|}
\hline \multirow[t]{2}{*}{ Treatments } & \multicolumn{3}{|c|}{$\begin{array}{c}\text { PPFM population in } \\
\text { phyllosphere (cfu/leaflet) }\end{array}$} & \multicolumn{3}{|c|}{$\begin{array}{l}\text { PPFM population in } \\
\text { rhizosphere }\left(10^{3} \mathrm{cfu} / \mathrm{g} \text { of soil }\right)\end{array}$} \\
\hline & $\begin{array}{c}\mathrm{W}_{1} \text { - } \\
\text { Normal } \\
\text { condition }\end{array}$ & $\begin{array}{c}\mathrm{W}_{2}- \\
\text { Drought } \\
\text { condition }\end{array}$ & $\begin{array}{c}\text { T } \\
\text { Mean }\end{array}$ & $\begin{array}{c}\mathrm{W}_{1}- \\
\text { Normal } \\
\text { condition }\end{array}$ & $\begin{array}{c}\mathrm{W}_{2}- \\
\text { Drought } \\
\text { condition }\end{array}$ & $\begin{array}{c}T \\
\text { Mean }\end{array}$ \\
\hline$T_{1}$ - Control & 45 & 32 & 38.5 & 19 & 14 & 16.5 \\
\hline$T_{2}$ - Seed treatment of PPFM & 50 & 35 & 42.5 & 22 & 18 & 20.0 \\
\hline$T_{3}$ - Soil application of PPFM & 47 & 33 & 40.0 & 22 & 18 & 20.0 \\
\hline$T_{4}$ - Foliar spray of PPFM & 59 & 42 & 50.5 & 20 & 15 & 17.5 \\
\hline $\begin{array}{l}\mathrm{T}_{5} \text { - Seed treatment + Soil } \\
\text { application of PPFM }\end{array}$ & 54 & 38 & 46.0 & 25 & 20 & 22.5 \\
\hline $\begin{array}{l}T_{6}-\text { Seed treatment }+ \text { Foliar } \\
\text { spray of PPFM }\end{array}$ & 63 & 44 & 53.5 & 21 & 18 & 19.5 \\
\hline W Mean & 53.0 & 37.3 & 45.2 & 21.5 & 17.2 & 19.3 \\
\hline & W & $\mathbf{T}$ & $\mathbf{W} \times \mathbf{T}$ & W & $\mathbf{T}$ & $\mathbf{W} \times \mathbf{T}$ \\
\hline $\mathrm{CD}(\mathrm{P}=\mathbf{0 . 0 5})$ & 0.49 & 0.85 & 1.20 & 0.20 & 0.36 & 0.51 \\
\hline SEd & 0.24 & 0.42 & 0.49 & 0.10 & 0.17 & 0.25 \\
\hline
\end{tabular}

Table.5 Effect of PPFM on proline content $\left(\mu \mathrm{g} \mathrm{g}^{-1}\right)$ in cluster bean

\begin{tabular}{|l|c|c|c|}
\hline \multicolumn{1}{|c|}{ Treatments } & $\begin{array}{c}\mathbf{W}_{\mathbf{1}} \text { - Normal } \\
\text { condition }\end{array}$ & $\begin{array}{c}\mathbf{W}_{\mathbf{2}} \text { - Drought } \\
\text { condition }\end{array}$ & T Mean \\
\hline $\mathbf{T}_{\mathbf{1}}$ - Control & 8.40 & 13.50 & $\mathbf{1 1 . 0}$ \\
\hline $\mathbf{T}_{\mathbf{2}}$ - Seed treatment of PPFM & 12.04 & 15.15 & $\mathbf{1 3 . 6}$ \\
\hline $\mathbf{T}_{\mathbf{3}}$ - Soil application of PPFM & 12.46 & 15.60 & $\mathbf{1 4 . 0}$ \\
\hline $\mathbf{T}_{\mathbf{4}}$ - Foliar spray of PPFM & 13.86 & 17.55 & $\mathbf{1 5 . 7}$ \\
\hline $\begin{array}{l}\mathbf{T}_{\mathbf{5}} \text { - Seed treatment + Soil application } \\
\text { of PPFM }\end{array}$ & 12.88 & 16.20 & $\mathbf{1 4 . 5}$ \\
\hline $\begin{array}{l}\mathbf{T}_{\mathbf{6}} \text { - Seed treatment + Foliar spray of } \\
\text { PPFM }\end{array}$ & 14.98 & 18.90 & $\mathbf{1 6 . 9}$ \\
\hline W Mean & $\mathbf{1 2 . 4 0}$ & $\mathbf{1 6 . 2 0}$ & $\mathbf{1 4 . 3}$ \\
\hline & $\mathbf{W}$ & $\mathbf{T}$ & $\mathbf{W} \mathbf{~ T}$ \\
\hline CD $(\mathbf{P = 0 . 0 5 )}$ & 0.15 & 0.27 & 0.39 \\
\hline SEd & 0.07 & 0.13 & 0.19 \\
\hline
\end{tabular}

Production of the plant growth regulators like auxins, particularly IAA and indole-3-pyruvic acid, and reacted cytokinins by Methylotrophs enhances plant growth of cluster bean. All the treatments under water stress condition recorded reduction in morphological parameters like plant height, number of leaves, leaf area as compared to plants with normal irrigation.

Cluster bean plants exposed to water stress showed delayed flowering, delayed harvest and lesser yield when compared to the plants which received normal watering. The highest 
root length was observed in the plants subjected to water stress. The phyllosphere population was higher in the seed treatment combined with foliar spray of PPFM irrespective of the water regimes. Seed treatment combined with soil application of PPFM registered highest rhizosphere population irrespective of the water regimes (Table 4). In this study, the data revealed that PPFM had several positive effects at the morphological and biochemical levels of cluster bean which can improve the yield under water stress when compared to control. Results showed that PPFM on water stressed cluster bean plants significantly improved both biometrical and yield attributes. This study confirms that seed treatment and foliar spray of PPFM can mitigate the deleterious effect of water stress on growth and yield in cluster bean.

Plant height and Biomass under well-watered conditions, PPFM significantly increased all the growth parameters like plant height, number of leaves, leaf area and root length in comparison over drought stress treatment. The maximum increment in plant height was observed in plant treated with PPFM as seed treatment and foliar spray followed by seed and soil application. The study revealed a prominent increment in root length in water stressed treated plants over well watered plants. However, the best results were observed in plants inoculated with PPFM as seed treatment and foliar spray. This enhancement in growth and biomass in cluster bean treated with PPFM may be due to the excretion of plant growth hormones like auxins and cytokinins by PPFM that influence germination and root growth and play critical role in a plant's response to water stress (Long et al., 1997). PPFM bacterial accumulation is the source of auxins production that led to develop of leaf area. Production of auxins can effect positively on leaf cells wall to become soft, so that leaf area be expanded (Taiz and Zeiger, 1998). Similarly, the increase in the vegetative growth of the plant attributed to the increase in the yield of a crop. Release of growth promoting substances like IAA and GA, proliferation of beneficial organisms in the phyllosphere leads to control of plant pathogens in addition to growth promotion.

Proline is an important amino acid in plant under drought stress that prevents oxidation of cells from inside. It also regularizes osmotic pressure of plant under drought stress for absorbing water. Drought stressed plants have been shown to accumulate organic osmolytes such as sugars and amino acids, known to have contribution in host plant tolerance under water deficit conditions (Schellembaum et al., 1998, Trotel-Aziz et al., 2000). Proline is a nonprotein amino acid that forms in most tissues subjected to water stress and, together with sugar, it is readily metabolized upon recovery from drought. Proline content was found to be more in stressed plants as compared to well water plants. The accumulation of proline was found to be maximum in the plants with seed treatment combined with foliar spray of PPFM (Table 5). The result of the study is in accordance with Porcel and Ruiz-Lozno (2003) in Soybean plant inoculated with PPFM under drought stress. Similar results were recorded by Aliabadi et al., (2008) in Coriandrum sativum. This study demonstrates that PPFM may enhance cluster bean yield in an environment characterized by soil moisture stress or low rainfall during growth period. From the foregoing results it can be concluded that the highest growth and yield parameters were recorded under treatment T6 (Seed Treatment + Foliar Spray) possessed several positive traits towards water stress. Hence this treatment may be studied in detail and can be exploited for alleviating drought stress and to reduce the amount of chemical fertilizer used in agriculture. Now-a-days bio-fertilizers are used to regulate and enhance the plant growth and protecting the plants against water stress in an eco-friendly way.

\section{References}

Abdelmoneim TS, Tarek A, Moussa A, Almaghrabi O, Hassan A and Alzahrani S. Increasing plant tolerance to drought stress by inoculation with arbuscular mycorrhizal fungi. Life Science Journal 
2014; 1(1):10-17.

Aliabadi HF, Mohammad Hossain Lebaschi and Aidin Hamidi. Effects of Arbuscular Mycorrhizal Fungi, Phosphorus and water stress on quantity and quality characteristics of Coriander. Advances in Nature and Applied Science 2008; 2(2):55-59.

Bates LS, Waldren RP and Teare ID. Rapid determination of free proline for water stress studies. Plant Soil 1973; 39:205207.

Boutraa $\mathrm{T}$ and Sanders FE. Influence of water stress on grain yield and vegetative growth of two cultivars of bean (Phaseolus vulgaris L.). Journal of Agronomy and Crop Science 2001; 187: 251-257.

Holland MA and Polacco JC. Urease-null and hydrogenase-null phenotypes of a phylloplane bacterium reveal altered nickel metabolism in two soybean mutants. Plant Physiology 1992; 98: 942948.

Long R, Morris R and Polacco J. Cytokinin production by plant-associated methylotrophic bacteria. Plant Physiology 1997; Abstract No. 1168.
Porcel R, Barea JM and Ruiz-Lozano JM. Antioxidant activities in mycorrhizal soybean plants under drought stress and their possible relationship to the process of nodule senescence. New Phytology 2003;157: 135-143.

Ruiz-Lozano JM. Arbuscular mycorhhizal symbiosis and alleviation of osmotic stress: new perspectives for molecular studies. Mycorrhiza 2003; 13:309-317.

Schellembaum, L., Müller J, Boller T, Wienken A and Chuepp H. Effects of drought on non-mycorrhizal and mycorrhizal maize: change in the pools of non-structural carbohydrates, in the activities of invertase and trehalase and in the pools of amino acids and imino acids. New Phytology 1998;138: 59-66.

Taiz, L. and E. Zeiger E. 1998. Plant physiology. Sunderland: Sinauer Associates Publishers, Sunderland, Massachusetts.

Trotel-Aziz, P., M.F. Niogret and F.Larher. Proline level is partly under the control of abscisic acid in canola leaf discs during recovery from hyper-osmotic stress. Physiology of Plant 2000; 110: 376- 383.

How to cite this article:

Nithya Devi, A.and Subasri, M. 2020. Interactive Effect of PPFM on Growth and Yield of Cyamopsis tetragonoloba (L.) under water stress. Int.J.Curr.Microbiol.App.Sci. 9(09): 1389-1395. doi: https://doi.org/10.20546/ijcmas.2020.909.176 